REVIEW SERIES

\title{
Cough . 7: Current and future drugs for the treatment of chronic cough
}

\section{G Belvisi, P Geppetti}

Thorax 2004;59:438-440. doi: 10.1136/thx.2003.013490

There are currently no effective treatments for controlling the cough response with an acceptable therapeutic ratio. However, several new mechanisms have been identified which may lead to the development of new drugs.

See end of article for authors' affiliations

Correspondence to: Professor M G Belvisi Respiratory Pharmacology
Group, Department of Cardiothoracic Surgery, Faculty of Medicine, Imperial College at the National Heart \& Lung Institute, Dovehouse Street, London SW3 6LY, UK; m.belvisi@ic.ac.uk

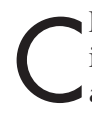
hronic cough is associated with many inflammatory airways diseases such as asthma, chronic obstructive pulmonary disease (COPD), post viral infections, pulmonary fibrosis, and bronchiectasis. Indeed, it is the first and most persistent symptom of diseases such as asthma and COPD. ${ }^{12}$ Furthermore, it is the most common respiratory complaint for which medical attention is sought and, although UK annual sales of over the counter (OTC) cough remedies are over $£ 0.5$ billion, effective treatments for cough are very limited. In fact, a recent study has suggested that OTC medicines for acute cough cannot be recommended because there is no good evidence for their effectiveness given that, even in studies where OTC compounds showed minimal benefits, these were of doubtful clinical relevance. ${ }^{3}$ The identification of new therapeutic targets for the treatment of chronic cough will therefore be of immense therapeutic benefit and will greatly enhance the quality of life of patients.

\section{CURRENT TREATMENTS \\ Opiates}

The most effective antitussive agents are opioids such as morphine, diamorphine, and codeine which, in all probability, act both centrally on brainstem opioid receptors and on receptors located peripherally on sensory nerve endings in the airways. ${ }^{4}$ However, at their effective doses they also cause physical dependence, respiratory depression, and gastrointestinal symptoms. Morphine and diamorphine are very addictive but are useful in treating severe distressing cough in patients with terminal illness such as bronchial carcinoma. Several opiate-containing proprietary cough mixtures contain low doses of weaker opioids such as codeine, but there is no strong evidence that these are more effective than the demulsant vehicle.

\section{Non-narcotic antitussive agents}

Dextromethorphan is the dextro isomer of the opiate levomethorphan and it has no analgesic or sedative properties. Dextromethorphan is the most commonly used antitussive in the USA.
Orally administered dextromethorphan is as effective as codeine in suppressing cough and has been used as a constituent of many OTC preparations. Furthermore, recent reports suggest that patients with an opioid resistant cough achieved symptomatic relief with the peripherally acting non-opioid drug benzonatate. ${ }^{5}$ Levodropropizine, oxalamine, and prenoxdiazine are available as cough treatments in Europe. Clinical studies have shown favourable data with levodropropizine in cancer related cough. ${ }^{6}$

\section{Local anaesthetics}

Local anaesthetics such as lignocaine are delivered locally to the airways and have been shown to attenuate capsaicin induced cough in humans. ${ }^{7}$ However, the effect is transient and the antitussive effect is accompanied by oropharyngeal anaesthesia leading to an increased risk of aspiration of airway secretions and food. This treatment should be avoided in patients with asthma because it may induce severe bronchoconstriction. Interestingly, lozenges containing local anaesthetics are often used as OTC treatment for acute cough such as that following an upper respiratory tract infection.

\section{Menthol}

Menthol has been proposed as an antitussive treatment and has been shown to inhibit citric acid induced cough in normal volunteers, but to a lesser extent than lignocaine. ${ }^{8}$ However, it has advantages over lignocaine as menthol does not result in oropharyngeal anaesthesia and may therefore be a more selective antitussive treatment. ${ }^{9}$

\section{NEW TREATMENTS}

New drugs for the treatment of cough may be directed at an extremely heterogeneous group of targets. A major distinction in this regard is the ability of certain drugs to inhibit the underlying inflammatory process that under certain conditions cause cough-for example, anti-inflammatory drugs for the treatment of asthma or COPD or novel proton pump inhibitors as treatment for gastro-oesophageal reflux-or compounds that are targeted to inhibit sensory nerve activity directly which should, in theory, inhibit cough of any aetiology. However, here we would like to focus on compounds that can be classified as symptomatic antitussive agents which recognise as their main targets ion channels, receptors, or other molecules expressed peripherally in primary sensory neurons or by inhibition of central mechanisms. 


\section{Ligands acting at $\mathbf{G}$ protein coupled receptors New opioids}

In addition to the classical opioids such as enkephalins, $\beta$ endorphins, and dynorphins, new opioid peptides have been described which have functional effects in the airways-for example, the endogenous opioid peptide nociceptin/orphanin FQ and endomorphins 1 and 2 have recently been isolated..$^{10}$ Nociceptin and the endomorphins are structurally different from one another and from the classical opioids.

Three classical opioid receptors have been identified pharmacologically: $\mathrm{OP}_{1}$ (formerly the $\delta$-opioid receptor), $\mathrm{OP}_{2}$ (formerly the $\kappa$-opioid receptor), and $\mathrm{OP}_{3}$ (formerly the $\mu$-opioid receptor). The opioids currently used as antitussive treatment predominantly bind the $\mathrm{OP}_{3}$ receptor and are therefore associated with characteristic side effects. New opioid peptides such as the endomorphins also activate the $\mathrm{OP}_{3}$ receptor. However, the endogenous opioid peptide nociceptin/orphanin FQ has some homology to the dynorphin family but lacks the $\mathrm{N}$-terminal tyrosine residue which is essential for binding classical opioid receptors. Interestingly, nociceptin binds to the opioid receptor-like 1 receptor $\left(\mathrm{ORL}_{1}\right)$. Furthermore, ORL $\mathrm{O}_{1}$ has already been shown to inhibit sensory nerve function in guinea pig airways in vitro and may be an excellent target for new antitussive treatments. ${ }^{11}{ }^{12}$

\section{Neurokinin receptor antagonists}

Tachykinins such as substance P and neurokinin A have been shown to elicit cough, and neurokinin receptor antagonists have been shown to be effective antitussive agents in animal models. Data have implicated a role for the $\mathrm{NK}_{2}$ receptor and possibly the $\mathrm{NK}_{1}$ receptor in this antitussive action. In fact, the $\mathrm{NK}_{2}$ receptor antagonist SR 48968 has been shown to inhibit citric acid induced cough in conscious guinea pigs, ${ }^{13}{ }^{14}$ but an antitussive effect of $\mathrm{NK}_{1}$ receptor antagonists is still debated. Recent data have suggested a role for $\mathrm{NK}_{3}$ receptor activation in evoking a tussive response..$^{15}$ SB 235375, a high affinity selective, reversible, and competitive antagonist, is also effective against citric acid induced cough in guinea pigs. ${ }^{16}$ It is a low CNS penetrant compound and, as such, it has been suggested that this compound has a peripheral mechanism of action even though there have been no reports of the presence of functional $\mathrm{NK}_{3}$ receptor antagonists in the human lung.

\section{Bradykinin receptor antagonists}

Bradykinin has been shown to elicit cough in man, ${ }^{17}$ and exposure of guinea pigs to aerosols of citric acid (low $\mathrm{pH}$ solution) or capsaicin produces reproducible cough presumably initiated by the activation of $\mathrm{C}$ fibres.$^{18}$ Prior exposure of guinea pigs to bradykinin or the angiotensin converting enzyme (ACE) inhibitor captopril enhanced citric acid induced cough. In both cases this enhancement was prevented by treatment with the bradykinin $B_{2}$ receptor antagonist. ${ }^{18}$ Bradykinin induced sensitisation of $\mathrm{C}$ fibres may be the mechanism operative in ACE inhibitor induced cough where a proportion of patients receiving this treatment for hypertension or cardiac failure exhibit a chronic cough and increased cough sensitivity to citric acid or capsaicin. ACE is an enzyme which is involved in the breakdown of bradykinin and therefore it has been hypothesised that the increased levels of bradykinin in the airways of patients on ACE inhibitor therapy could cause sensitisation of airway C fibres leading to the enhanced sensitivity of the cough reflex which could theoretically be treated with $\mathrm{B}_{2}$ receptor antagonists. Consistent with these pharmacological data describing a role for bradykinin in ACE inhibitor cough are studies which show that bradykinin $\mathrm{B}_{2}$ receptor gene polymorphism is associated with ACE inhibitor related cough. ${ }^{19}$

\section{Inhibition of prostanoid synthesis/action}

The high tussive potency of the prostaglandins in humans suggests that their local release in various respiratory pathophysiological conditions may be responsible for the accompanying cough/irritancy. ${ }^{17}{ }^{20}$ In patients with asthma cough thresholds with indomethacin and OKY-046 (thromboxane synthase inhibitor) treatment were significantly greater than with placebo, which supports the hypothesis that thromboxane $\mathrm{A}_{2}$ may be one of the cyclooxygenase products augmenting airway cough sensitivity in asthma. ${ }^{21}$ Furthermore, it has been suggested that prostaglandins may have a role in the genesis of cough induced by ACE inhibitors, and inhibition of prostaglandin synthesis with indometha$\mathrm{cin}^{22}$ or a thromboxane antagonist ${ }^{23}$ can reduce or abolish the incidence of this side effect. However, although prostaglandins may be involved in cough associated with ACE inhibitor therapy, evidenced by the ability of the non-steroidal antiinflammatory sulindac to inhibit cough in patients on this treatment, the same compound was ineffective in patients not on ACE inhibitor therapy but with idiopathic dry unproductive cough. ${ }^{24}$

\section{Ion channel modulators}

Transient receptor potential (TRP) channels

Recently, receptors have been cloned on sensory nerves that are activated by thermal stimuli. The cold and menthol sensitive receptor (CMRl) has recently been characterised and cloned and is a member of the TRP family of excitatory ion channels. ${ }^{25}$ Interestingly, menthol has been proposed as an antitussive treatment and has been shown to inhibit citric acid induced cough in normal volunteers. ${ }^{8}$ Activators of this particular channel may therefore prove to be useful therapeutic agents. The heat sensitive channels VRI and VRL-1 are TRP channels that detect temperatures over a wide range. The VRl channel is activated by capsaicin, the main pungent ingredient in hot chilli peppers; however, the related channel VRL-1 does not respond to capsaicin but is activated by temperatures exceeding $50^{\circ} \mathrm{C} .^{26}{ }^{27}$ Since the actions of the sensory nerve stimulant capsaicin on sensory nerves may be mediated by activation of the VRl receptor, blocking these channels may be a good target for an antitussive treatment.

\section{Potassium channel openers}

In single fibre recording studies, NS1619, an opener of large conductance calcium activated potassium (BKCa) channels, has been shown to inhibit the firing of $\mathrm{A} \delta$ and $\mathrm{C}$ fibres innervating the guinea pig airway. In the same study the guinea pig tussive response elicited to citric acid was also inhibited by NS1619 which underlines the usefulness of this class of compounds for cough treatment in the future. ${ }^{28}$

Other workers have suggested that ATP sensitive potassium channels may be a good target following studies in which openers of these channels (pinacidil and cromakalim) reduced citric acid induced cough in guinea pigs. ${ }^{29}$

\section{Chloride channels}

It has been shown that frusemide can reduce the potentiation of capsaicin induced cough by prostaglandin $\mathrm{F}_{2 \alpha}\left(\mathrm{PGF}_{2 \alpha}\right)$. Frusemide had no effect on capsaicin induced cough alone. In view of these findings it has been suggested that changes in local ionic concentrations by frusemide, particularly chloride ions within the vicinity of epithelial cough receptors, may be responsible for this inhibitory effect. ${ }^{30}$

\section{CONCLUSIONS}

Treatment of the underlying cause of cough can often be effective-for example, inhaled corticosteroids for asthma related cough. However, at the moment there are no effective treatments controlling the cough response per se with an acceptable therapeutic ratio. There is therefore a need for 
more selective drugs with a favourable side effect profile. The future looks promising with identification of several new mechanisms which may lead to new drugs that target the increased sensitivity of sensory fibres resulting in exaggerated cough.

\section{Authors' affiliations}

M G Belvisi, Respiratory Pharmacology Group, Department of

Cardiothoracic Surgery, Faculty of Medicine, Imperial College at the National Heart \& Lung Institute, London, UK

P Geppetti, Department of Experimental and Clinical Medicine, Pharmacology Unit, University of Ferrara, Ferrara, Italy

\section{REFERENCES}

1 Choudry NB, Fuller RW. Sensitivity of the cough reflex in patients with chronic cough. Eur Respir J 1992;5:296-300.

2 Karlsson J-A, Sant'Ambrogio G, Widdicombe J. Afferent neural pathways in cough and reflex bronchoconstriction. J Appl Physiol 1988;65:1007-23.

3 Schroeder K, Fahy T. Systematic review of randomised controlled trials of over the counter cough medicines for acute cough in adults. BMJ 2002;324:1-6.

4 MacRedmond R, O'Connell F. Treatment of persistent dry cough: if possible, treat the cause; if not, treat the cough. Monaldi Arch Chest Dis 1999; 3:269-74

5 Doona M, Walsh D. Benzonatate for opioid-resistant cough in advanced cancer. Palliat Med 1998;12:55-8.

6 Homsi J, Walsh D, Nalson KA. Important drugs for cough in advanced cancer. Support Care Cancer 2001;9:565-74

7 Choudry NB, Fuller RW, Anderson N, et al. Separation of cough and reflex bronchoconstriction by inhaled local anaesthetics. Eur Respir J 1990;3:579-83.

8 Morice AH, Marshall AE, Higgins KS, et al. Effect of inhaled menthol on citric acid induced cough in normal subjects. Thorax 1994;49:1024-6.

9 Sant'Ambrogio FB, Anderson JW, Sant'Ambrogio G. Effect of L-menthol on laryngeal receptors. J Appl Physiol 1991;70:788-93.

10 Groneberg D, Fischer A. Endogenous opioids as mediators of asthma. Pulmonol Pharmacol 2001;14:383-9.

11 Fischer A, Forssman WG, Undem BG. Nociceptin induced inhibition of tachykinergic neurotransmission in guinea-pig bronchus. J Pharmacol Exp Ther 1998;285:902-7.

12 Shah D, Page CP, Spina D. Nociceptin inhibits non-adrenergic noncholinergic contraction in guinea-pig airway. Br J Pharmacol 1998; 125:510-6.

13 Advenier C, Girard V, Naline E, et al. Antitussive effect of SR 48968, a nonpeptide tachykinin NK2 receptor antagonist. Eur J Pharmacol 1993;250:169-71.
14 Girard V, Naline E, Vilain P, et al. Effect of the two tachykinin antagonists, SR 48968 and SR 140333, on cough induced by citric acid in the unanaesthetised guinea-pig. Eur Respir J 1995;8:1 $110-4$.

15 Daoui S, Cognon C, Naline E, et al. Involvement of tachykinin NK3 receptors in citric acid-induced cough and bronchial responses in guinea-pigs. Am J Respir Crit Care Med 1998;158:42-8.

16 Hay DWP, Giardina GAM, Griswold DE, et al. Nonpeptide tachykinin receptor antagonists. III. SB 235375, a low central nervous system-penetrant, potent and selective neurokinin 3 receptor antagonist, inhibits citric acidinduced cough and airways hyper-reactivity in guinea-pigs. J Pharmacol Exp Ther 2002; 300:314-23.

17 Choudry NB, Fuller RW, Pride NB. Sensitivity of the human cough reflex: effect of inflammatory mediators prostaglandin E2, bradykinin, and histamine. Am Rev Respir Dis 1989;140:137-41.

18 Fox AJ, Lalloo UG, Belvisi MG, et al. Bradykinin-evoked sensitization of airway sensory nerves: a mechanism for ACE-inhibitor cough. Nat Med 1996;2:814-7.

19 Mukae S, Aoki S, Itoh S, et al. Bradykinin B(2) receptor gene polymorphism is associated with angiotensin-converting enzyme inhibitor-related cough. Hypertension 2000;36:127-31.

20 Costello JF, Dunlop LS, Gardiner PJ. Characteristics of prostaglandin induced cough in man. Br J Clin Pharmacol 1985;20:355-9.

21 Fujimura M, Kamio Y, Kasahara K, et al. Prostanoids and cough response to capsaicin in asthma and chronic bronchitis. Eur Respir J 1995:8:1499-505.

22 Fogari R, Zoppi A, Tettamanti F, et al. Effects of nifedipine and indomethacin on cough induced by angiotensin-converting enzyme inhibitors: a doubleblind, randomized, cross-over study. J Cardiovasc Pharmacol 1992; 19:670-3.

23 Malini PL, Strocchi E, Zanardi M, et al. Thromboxane antagonism and cough induced by angiotensin-converting-enzyme inhibitor. Lancet 1997;350:15-18.

24 McEwan JR, Choudry NB, Fuller RW. The effect of sulindac on the abnormal cough reflex associated with dry cough. J Pharmacol Exp Ther 1990;255:161-4.

25 McKemy DD, Neuhausser WM, Julius D. Identification of a cold receptor reveals a general role for TRP channels in thermosensation. Nature 2002;416:52-8.

26 Caterina MJ, Schumacher MA, Tominaga $M$, et al. The capsaicin receptor: a heat activated ion channel in the pain pathway. Nature 1997;389:816-24.

27 Caterina MJ, Leffler A, Malmberg AG, et al. Impaired nociception and pain sensation in mice lacking the capsaicin receptor. Science 2000;288:306-13.

28 Fox AJ, Barnes PJ, Venkatesan P, et al. Activation of large conductance potassium channels inhibits the afferent and efferent function of airway sensory nerves in the guinea-pig. J Clin Invest 1997;99:513-9.

29 Poggioli R, Benelli A, Arletti R, et al. Anti-tussive effect of $\mathrm{K}^{+}$channel openers. Eur J Pharmacol 1999;371:39-42.

30 Ventresca PG, Nichol GM, Barnes PJ, et al. Effect of frusemide on the induction and potentiation of cough induced by prostaglandin $\mathrm{F}_{2}$ alpha. Br J Clin Pharmacol 1992;33:514-6. 